\title{
The Limits to Reform: A Critical Discussion of the Saskatoon Public School Board's Assessment Controversy
}

Robert LeBlanc

University of Pennsylvania

\section{Author Note}

I wish to thank Jeff Park, Shirley Steinberg, Gillian Breckenridge, Daniel LeBlanc, Jaime Sportun, and the reviewers of this paper for their helpful comments and suggestions. Special thanks are due to my good friends at the Freire Project for their continued support.

Correspondence concerning this article should be addressed to Robert J. LeBlanc, Penn Graduate School of Education, 3700 Walnut Street, Philadelphia, PA, 19104-6216. rleblanc@gse.upenn.edu

\begin{abstract}
This article presents a critical discussion of the controversy surrounding the perceived changes to the Saskatoon Public School Board's assessment policy in September 2010. Utilizing Critical Discourse Analysis (Fairclough, 2005; Gee, 2005) and a critical framework of curriculum reform (Apple, 1996, 2000), an analysis of media representations, government statements, and curriculum documents suggests that the general public outcry, the Saskatoon Public School Board's reaction to the controversy, and the government's response exemplify a tacit understanding of the socialization purposes of school in preparing students for the world of labour. This article further examines the influence of "conservative modernization" (Apple, 1996; Lankshear \& Gee, 1997; Gee, Hull, \& Lankshear, 1996) on Saskatchewan educational policies and the capacity of Saskatchewan schools to innovate.
\end{abstract}

Keywords: critical discourse analysis; critical framework; curriculum reform; socialization; educational policies 


\section{The Limits to Reform: A Critical Discussion of the Saskatoon Public School Board's Assessment Controversy}

The fast capitalist world, then, holds out deep opportunities and risks for those of us interested in education. If we as educators accept the fast capitalist vision uncritically, we risk becoming party to "enchantment" as a spell cast on workers to achieve a new "high technology" hegemony. We risk, too, collusion with the processes which create enchantment for some, but at the expense of possibly deeper disenchantment for many, and, ultimately, perhaps society as a whole. If we fail to engage with fast capitalism altogether, we risk being left on the sidelines as education at all levels simply aligns itself with the values, visions, and practices of fast capitalism. (Lankshear \& Gee, 1997, p. 90)

As a parent, I would be upset...Getting your work done on time matters in the workforce. (Premier Brad Wall, CBC News, September 29, 2010)

When the media first announced in September 2010 that the Saskatoon Public School Board was changing their assessment guidelines regarding late assignments and plagiarism, the response from the public and the provincial government was swift and condemnatory. Though the Board claimed they were promoting classroom practice resonant with contemporary research and the Ministry of Education's assessment policy, the public reaction, as expressed through television news, talk radio, and the internet, was a veritable landslide of popular resistance. This article presents a critical discussion of the controversy, and argues that the Saskatoon Public School Board's subsequent retraction of the proposed change and provincial government's scrutinizing of provincial assessment policy exemplifies the tacit understanding on the part of the public of the socialization purposes of school in preparing students for the world of labour. Utilizing Critical Discourse Analysis (Fairclough, 2005; Gee, 2005) and a critical framework of curriculum reform (Apple, 1996, 2000), I examine the influence of conservative modernization (Apple, 1996; Lankshear \& Gee, 1997; Gee, Hull, \& Lankshear, 1996) on Saskatchewan educational policies and the limitations this ideological stance places on the capacity of Saskatchewan schools to innovate.

The Saskatchewan economy is in the midst of one of the most robust expansions in its history. Previously mired in decades of high unemployment, tepid economic growth, and a depressed commodities market, Saskatchewan has recently emerged as a bona fide economic powerhouse, riding a wave of increased employment and population, thanks in no small part to the skyrocketing prices of petroleum and potash (The Economist, June 5, 2008). On the Canadian scene, Saskatchewan has transformed from a "have not" to a "have" province in a relatively short period of time. While the net result of these economic gains for the whole province can be debated, Saskatchewan is undoubtedly going through a "boom" period (Campbell, 2011). The present government would like to claim these gains as a direct result of their economic policies (the contents of which are far beyond the scope of this discussion) (Ministry of Advanced Education, Employment and Labour, 2008).

However, along with these economic gains has come a corresponding move toward neoliberal governmental policy, which has been felt across education, social services, and economic sectors. This includes an increased willingness to grapple with organized labour (including a revision of Essential Services legislation) (Cameron, 2008), a lowering of indirect taxes (Ministry of Finance, 2011), and the initiation of bi-lateral talks with other Western 
provinces to discuss the dismantling of economic and educational barriers (New West Partnership, 2010). This also includes an alignment of schools with the demands of industry (Saskatchewan Party, 2007).

My intent is not to provide an abstract theorization. Rather, I intend to utilize theoretical models of cultural action (Gee, 1992, 2005) to explore this relevant Saskatchewan educational example, which has significant implications for the day-to-day practice of teachers across the province. To date, Saskatchewan schools have largely avoided the more pernicious standardization tendencies that characterize their American neighbours, including streamlined instructional practices and a loss of supervisory control by unions.

However, increased support for these kinds of policies by particular segments of the population is indicative of an enlarged willingness to theorize schools as little more than training grounds for the workforce. My stance here is not an alliance with rather utopian views of education in the 1950s and 60s (cf. Apple, 1996; Giroux, 1981), which posit those "halcyon days" as a golden era when schools were about engendering a democratically engaged populace (as though schools were ever severed from the demands of industry and capital). Rather, I simply want to acknowledge the burgeoning shift in the province regarding the purpose of education, a reconstitution of both what education is about and what it is for. While there is not enough space here to present a total description of this ongoing project, I do want to argue that the kinds of public limitations placed on the Saskatoon Public School Board in regards to their assessment guidelines is a concrete instantiation of that shift.

\section{Background to the Controversy}

By chance, I was at home in Saskatchewan visiting my parents when the CBC first reported that the Saskatoon Public School Board was changing their assessment guidelines. In a conventionally contemporary way, I first heard about it online; my inbox exploded with emails from friends and colleagues expressing outrage at the proposed changes and from others expressing outrage at the level of outrage. Within a few hours, this seemingly innocuous move on the part of the Board was the top news in the province. The story featured prominently in several newscasts over the following days, and a cadre of administrators, politicians and representative individuals were weighing in on the matter. National media outlets, including the National Post and Maclean's, were soon covering the matter. Professors at the University of Regina were consulted for their thoughts on the impact the proposed changes might have on the quality of university students' work (CBC, September 28, 2010). Donna Harpauer, Minister of Education, expressed her deep concern with the move (CBC, September 30, 2010). Even Premier Brad Wall proffered his opinion on the subject (CBC, September 29, 2010).

To many of us in education, the Board's proposed changes seemed rational and unexceptional, especially in light of a number of Ministry documents, which seemingly supported a move to separate assessment from classroom conduct issues (for example, Saskatchewan Ministry of Education, 2010b). The CBC reported (CBC, September 27, 2010) that Saskatoon Public School Board teachers were encouraged to treat issues such as plagiarism and lateness on assignments as behavioural concerns, rather than reflecting them in grading. Marks were not to be deducted for behavioural problems (attendance, plagiarism, lateness). This was, in many ways, contrary to common practice for many teachers. In the economy of schooling, grades are one of the few tools teachers deploy in order to ensure student work is completed to the standards schools require. However, the Board was adamant that this was only 
to keep their practice in compliance with several Ministry directives regarding assessment. Rather than losing marks for plagiarism or lateness, students would receive support or indeed punishment; however, their grades on assignments were only to reflect their actual demonstration of curricular objectives, to the exclusion of all other factors.

This move was in many ways resonant with psychometric models of education and assessment (Li, 2003; McMillan, 2007; Yu, 2005; for an authoritative critique of this model, see Heap, 1980). My intent is not to garner support for this kind of assessment policy; there is nothing especially progressive about it. Many American states have similar policies that they utilize in full support of the assessment regime required by the No Child Left Behind Act. The logic behind this practice is that in order to properly ameliorate any deficiencies in the child's learning, it is crucial to have accurate, "scientific" data that demonstrates only the child's performance of the assessment's objectives. This kind of "clinical” approach is deployed to support treatment for the child (treatment, I note in passing, which is intrinsically bound up with an entire industry of publications and packaged classroom instruction) (Epstein, 2006). I mention this to highlight that this separation of behavioural and curricular assessment is not particularly liberal in the pejorative way some of its critics use the word. My critique of the provincial government's reaction against the Board's proposed policy is in no way an indication of my support for these changes. These kinds of psychometric models can be, and have been, deployed by more conservative groups (or in the present American situation, neoliberal education policies).

There is no doubt, however, that the Ministry's own documents support this kind of practice. From the following Ministry of Education's updated Communications Media 10, 20, 30 curriculum documents (Saskatchewan Ministry of Education, 2010a):

Assessment and evaluation require thoughtful planning and implementation to support the learning process and to inform teaching. All assessment and evaluation of student achievement must be based on the outcomes in the Communications Media curriculum [emphasis added]....Evaluation compares assessment information against criteria based on curriculum outcomes for the purpose of communicating to students, teachers, parents/caregivers, and others about student progress and to make informed decisions about the teaching and learning process. Reporting of student achievement must be based on the achievement of curriculum outcomes [emphasis added]. (p. 25)

This language is effectively replicated in all other Saskatchewan curriculum documents' statements on classroom assessment.

This does not mean that there are no consequences for behaviours such as plagiarism or lateness, a fact that Board Chair, Ray Morrison, had to explicitly point out (Coles \& Morrison, September 30, 2010); rather, that they are to be dealt with separately. This is a fact the media and the provincial government seem to have blithely missed. For example, the lead headline on the CBC website when the story broke was "Saskatchewan schools go easy on plagiarism" (CBC, September 27, 2010). One wonders how a child who received a detention for plagiarizing an essay (which she then had to rewrite) would respond to the notion that she got it easy. In a media release, the Ministry of Education explicitly told schools "not to condone plagiarism or late assignments" (CBC, October 5, 2010). The thematic trend online and in the televised news was that schools were not "holding kids accountable" for their work. 
Soon after the story broke, weighed down by a landslide of public pressure exerted via the television media, talk radio, and various other online venues (to say nothing of the volume of calls they fielded), the Saskatoon Public School Board went on the defensive to justify and later to clarify their position (Coles \& Morrison, 2010 September 30). Board Chair, Ray Morrison (CBC, September 30, 2010), claimed that there had been a "miscommunication" and that if plagiarism occurs, "a student will be given a zero.” If Morrison's rearticulation of the Saskatoon Board's policy sounded like a retraction-particularly in light of the rather clear statement on the guidelines made by superintendent John Dewar only days earlier (CBC, September 27, 2010) —it is little wonder given the kind of political duress he was under. Within days of the first story airing, Minister of Education, Donna Harpauer, claimed that the proposed changes were a misreading of Ministry documents, and that in no way was the Ministry's position in support of separating behavioural concerns from assessment. (CBC, October 5, 2010). The Premier himself expressed a deep dissatisfaction with the very idea and proposed a provincial-wide investigation into other divisions' assessment policies, with the expressed intent of considering a standardized assessment practice for all schools in Saskatchewan (CBC, September 29, 2010).

\section{Theoretical Foundations}

In this section, I describe my conceptualization of the ideological, political, and cultural forces acting on educational policy in Saskatchewan. This conceptualization borrows extensively from the work of Michael Apple (1996, 2000), particularly his bifurcation of neoconservative and neoliberal political movements, and their unity in what he deems (after Roger Dale, 1989) conservative modernization. Furthermore, my theorization of neoliberal policies is grounded in the work of Gee, Hull, and Lankshear (1996) around the idea of fast capitalism, and David Harvey's extensive writing on neoliberal economic policy in Britain and the United States (cf. Harvey, 2005, 2006). I will argue that this particular ideology-conservative modernizationhas become resonant in Saskatchewan, an ideology rooted in the ideals of (1) neoconservativism and neoliberalism, and (2) fast capitalism, as exemplified in the public's reaction to the Saskatoon Public School Board’s assessment guidelines.

\section{Ideology and Common Sense}

A discussion of a particular ideology first requires defining what I mean by ideology. This is a complex task. Ideology is often thought of negatively, as though it were something to be overcome or escaped from (as if it could be). This common understanding of ideology is in many ways indebted to its roots in early critical/neo-Marxist literature, which posited the very idea as something false and obfuscating, often foisted upon a social group in a top-down manner. A much more generous conception of ideology is required, however. A more accurate theory of ideology would acknowledge both its situatedness (formed on the spot using linguistic resources, cf. Gee, 1996), and its everydayness (patterned actions of daily living, cf. Street, 1995). Bernier and Williams (1973) describe ideology as "an integrated pattern of ideas, systems of beliefs, or a "group consciousness" which characterizes a social group” (p. 27), a stance that highlights ideology’s commonness and pervasiveness.

Ideology is not easily located within a group of people (Gee, 1996). Ideologies are always contested spaces, vying for attention, status, prestige, and definition, even within seemingly homogenous social groups. Street (1995) describes this ideological contestation as "the site of tension between authority and power on the one hand and individual resistance and creativity on the other” (p. 162). Ideologies are often a terrain where a balancing act is being performed 
between the cultural models of socially appropriate action (what Wittgenstein called forms of life) and the capacity of human actors to innovate these existing folk models. To borrow a term from traditional critical literature, ideologies are dialectical.

Equally, ideologies are not foisted upon people. They are not "received from on high" or "disseminated" in a pure form that is uncritically received by a social group. They are not contained in a single social class, as though you could describe someone's ideology simply by locating that person in a field of cultural or economic power. As Michael Apple (2000) describes, "Ideologies, properly conceived, do not dupe people. To be effective, they must connect to a real problem, real experiences” (p. 20). A successful ideology is rooted in the daily lives of individuals, concretized as explanations for the day-to-day phenomena that most people face in a given social network. Narrative, therefore, is a crucial strategy for any ideology. Ideologies that explain the world in a socially resonant way are often perceived to have more authority with the result of eclipsing the possibility of others.

The success of any ideology is dependent upon its capacity to filter core ideas to a broader population, to define the terms of discourse in any given subject, to become a kind of "common sense" among a population so that the "feel for the game" of a particular ideology is acquired by that social group (Fairclough, 1989). This can often be expressed through the articulation of core values for a population- ideology's task is to set the baseline for discussion.

Moving this discussion forward into the realm of education, I suggest that a particular ideology, conservative modernization, has become prevalent in the discourse on schools in Saskatchewan. This ideology, which has not been imposed by a particular group but has developed for complex and varied historical, cultural, and economic reasons, has now set the baseline for what qualifies as common sense in discussing the role of schools in society. In the discussion about the Saskatoon Public School Board's assessment policy, this means that the given perspective on schools is wrapped in a narrative that denigrates schools as disconnected from both common sense values (such as getting work done on time) and as incapable of producing effective types of workers (who perform to task). And, while this may seem as though it were everyday thinking, it is a substantial reconstitution of a societal perspective on the purpose of schools (for an example of various historically-rooted visions of the purpose of schools, see Graff, 1987). By highlighting the ideological nature of this take to the controversy, I am positing that it could be otherwise.

In the case of Apple's (2000) discussion of Reagan and Thatcher's ideology in the United States and Britain during the 1980s, he rather ungenerously refers to the general adoption of their economic and cultural reforms by the population as "authoritarian populism.” By this he means the adoption of what he deems socially regressive economic and cultural policies which curtail the gains made by organized labour and formerly excluded populations in the 1960s and 70s: He describes it as a policy "based on an increasingly close relationship between the government and the capitalist economy, a radical decline in the institutions and power of political democracy" (p. 21). Furthermore, this populist group is deeply concerned with issues of "security, the family, and traditional knowledge and values" (Apple, 1996, p. 6), gathered together into a considerable political bloc that Apple often refers to as the "New Right". By "New," Apple means the contemporary phenomenon of the fusion of traditional conservative populist movements with contemporary market influences. Apple's concern is the capacity of this New Right to dictate the kind of discourse possible in educational conversations, both around the kind of heightened cultural politics that marked the 1980s, but also around the fundamental purpose of schools. This 
is an example of the dissemination of an ideology across a broad population that sets limits to the kind of 'common sense' that can exist in a particular area.

\section{Neoconservative and Neoliberal Ideology}

In an attempt to understand the seemingly contradictory drives in American education toward both increased standards and accountability, and freedom and choice, Apple (1996, 2000) theorizes the duel work of neoconservative and neoliberal forces acting together in what he calls conservative modernization. This new movement drastically reconfigures the purposes of schooling, as well as the work of the state, in somewhat contradictory ways.

Apple (1996) describes the neoconservative movement as a portion of a "conservative restoration" (p. 28) that seeks to re-establish the role of "traditional” values in society through political action. This includes a devaluation of schools for their supposed "antifamily bias" and their liberal utopianism that severs the work of schools from the knowledge and values of the "Western tradition" and "real knowledge." In short, this is an appeal to a kind of culturally specific common sense. Neoconservative movements seek to transform schools through political engagement, and in doing so ensure that family values are reinserted into what is derided as secular and overly idealistic terrain.

Apple (1996) recognizes, however, that this is not sufficient to explain the present marketfocused direction of education, particularly in the United States. Here Apple introduces neoliberalism as a corresponding and uniting force with neoconservativism. By neoliberal, Apple (1996) means forces committed to "the expansion of the 'free market', the drastic reduction of government responsibility for social needs...the reinforcement of intensely competitive structures of mobility, [and] the lowering of people's expectations for economic security" (p. 28). This is effectively a weak state argument for the modern world, in exchange for a robust marketplace (though this vision of neoliberalism is hotly contested-David Harvey (2005, 2006), for example, argues that neoliberalism encourages a strong state in very particular areas, notably foreign policy, as an enabler for market expansion). In a system that enlarges the process of buying and selling to become a totalizing societal ethic, it is little wonder that educational issues are equally regarded as platforms for the creation of a workforce that is able to operate fluidly under such circumstances. Neoliberalism's goal is to ensure a capable workforce in a newly evolved economy under the banner of the "standards and excellence" (Apple, 2006) educational movement, often utilizing the business-derived rhetoric of Total Quality Management and Continuous Improvement in the process. For example, Saskatchewan's "Continuous Improvement Framework” (Saskatchewan Ministry of Education, 2008) is nearly a wholesale adoption of this business language into educational projects.

When these two are brought together under the banner of conservative modernization, they promote what Dale (1989) calls a "small, strong state” (pp. 4). Appeals for change are consequently argued at the following two levels: to a restoration of traditional values rooted in common sense, and to a free market ethic that nakedly correlates the work of schooling with the preparation for entrance into the labour market.

\section{Fast Capitalism}

Fast capitalism is a term used by Gee, Hull, and Lankshear (1996; see also Lankshear \& Gee, 1997) to describe the new work order that exists in the modern North American economy. This includes the post-industrial conditions that mar many communities (Detroit being the prime 
example) and the increased destabilization of traditional labour under the weight of global capitalism. Capitalism is now "fast" because it demands a rapidity of change on the part of business and the "highly-skilled" labour force that undermines traditional notions of "lifetime employment' and national affiliations for companies.

Gee, Hull, and Lankshear (1996) describe how industry now tells a story to explain the need for radical restructuring of labour conditions and capital. They call this narrative the "textual creation of a new Discourse... with new social identities" (p. 26). The story is well trodden (for a popular contemporary example, see Thomas Friedman's, The World is Flat, 2005), but portions of it bear repeating here.

After years of virtual dominance in the international marketplace, thanks in no small part to its seemingly endless resource supply, the Western powers now face sharp global competition from emerging economies as a result of globalization. China, India, Brazil, and other more developed economies now pose a serious challenge to American economic pre-eminence. This globalizing trend is coupled with a shift in consumer preferences for individualized products. In the light of this increased competition and the decline of traditional large-scale manufacturing, companies must now be "leaner and meaner", shedding much of their excess "waste" in order to remain competitive in the global market. This is equally true at a national level. Countries must now pour all their resources into ensuring their workforce is "highly trained" and "mobile" in order to adapt to the transformed economy (which is often symbolic rather than physical).

This has a profound impact on education. Schools are now seen as key cogs in the process of creating a contemporary workforce that suits the "fast capitalism" criteria. This is conducted in a variety of ways, including explicit curricular changes (increased vocational training, streaming, etc.) and more subtle alignments (cf. Goddard, 2009). Often schools are expected to unite the day-to-day practice of education with industry by both the official authorities and a host of other social groups who want to ensure their children/communities/countries are capable of competing under the new conditions. This is not simply a top down mandate (though it can be). Schools receive political pressure in a variety of ways from a variety of groups. At the core of this emerging movement, however, is a need for the school to see itself as a core producer of a particular kind of worker through all facets of education. This includes things like the production of particular kinds of work (on time, of their own) in particular kinds of circumstances (in collaborative teams, etc.). The notion is that "every successful worker builds up knowledge about his or her job that is derived in part from participation in a community of practice” (Gee, Hull, \& Lankshear, 1996, p. 66). The school's task is to create a community of practice in their own building that is resonant with future labour. Schools that do not align themselves with this mandate are seen as failing their students.

The problem with this ideology (and its relative pervasiveness in North America) is that schools are already prone to producing types of workers that fall along traditional class lines (for some classic examples of this reproductive process, see Apple, 1980; Bourdieu \& Passeron, 1977; Bowles \& Gintis, 1976; Erickson, 1988; Willis, 1977). To use a familiar example, Jones’s (1991) study of two classrooms in an all-girls school demonstrates how white, middle-class students (from professional and business families) are inculcated with particular habits through instruction that correlates to future work (problem solving, asking questions, collaborative group projects) while migrant working-class students were instilled with a completely different type of work habits (respect for authority, passively receiving information, listening). Even when both groups of students work hard in their respective contexts, they are effectively being groomed by 
the process of schooling for a particular kind of future work. Whether or not students effectively accepted those habits of labour (research would strongly suggest they do not, cf. McNeil, 1988; Willis, 1977) is beside the point, in this case. The structure of schools-intended or notincreasingly correlates to conditions of the work world.

By identifying prominent ideological conceptions of the relationship between economics and schools we can note some of the ways in which these powerful or dominant ideologies influence discussions of education at both the meta-level, and in more mundane and everyday practices. To develop this argument, I examine a short piece of text that is pertinent to the discussion of educational ideology in Saskatchewan as manifest through the controversy over Saskatoon Public's assessment policy.

\section{An Example of Conservative Modernization}

I would like to turn now to a short example of this kind of conservative modernization at work in Saskatchewan. The excerpt below was taken from a September 29, 2010 interview that Saskatchewan Premier Brad Wall gave with the CBC regarding the Saskatoon Public School Board's assessment policy. Of particular interest in this brief excerpt is the concretization of the melding of neoconservative and neoliberal ideologies.

It is important to reiterate that the dissemination and support of any ideology does not work in a unilateral, top-down manner, as though it can be imposed on a population from above. Rather, ideology moves in coordinated patterns in complex ways across and amongst various groups, often inhabiting seemingly contradictory classes and individuals. Consequently, by illustrating a particular ideological expression of the Premier of Saskatchewan, I am not claiming that this is somehow representative of the entire province, or even of his party. That being said, it would be absurd not to recognize that Brad Wall is a person with considerable political clout, and that his voice carries more "cultural capital" (Bourdieu \& Passeron, 1977) than others in many social groups, including the Ministry of Education.

When asked about the possibility of late assignments receiving no academic penalty, Wall responded:

As a parent, I would be upset. It doesn't fit with what Tami and I ask our kids to do. We ask our kids to get their assignments in on time.... We need to be providing an education for young Saskatchewan people both at the secondary and post-secondary level that gets them ready for the workforce. Getting your work done on time matters in the workforce. (Premier Brad Wall, CBC News, September 29, 2010)

The Premier's denunciation of the Saskatoon School Board's assessment policy is rooted in a two-fold appeal to traditional family values and the pressing needs of the marketplace economic rationality: His diagnosis assembles an ideology of conservative modernization. This particular account proposes that the values rooted in traditional families toward work should be reflected in schools, and that schools are equally a contributing partner in providing a skilled workforce by inculcating particular habits toward work. In this, Wall is creating a "sensible explanation" that connects "to the real hopes, fears, and conditions of people's daily lives" (Apple, 1996, p. 45).

Utilizing Gee’s (2005) framework for Critical Discourse Analysis, I would like to look at the taken-for-grantedness of Wall's discourse, to examine what activities, identities, and connections he is performing in regards to a crucial educational policy. My approach to Critical 
Discourse Analysis is particularly concerned with the capacity of texts to formulate identities (Fraser, 1991; Gee, 1996) through language, as language is the primary means by which we experience politics (Fairclough, 2005). As I examined the text, I was continually mindful of Bacchi's (1999) "What's the problem?" strategy of discourse analysis, which focuses on how the implicit problem in the text is typically discursively constructed with a tacit diagnosis for how it should be solved. My analysis is consequently far more concerned with the social uses and implications of the text than with grammatical parsing.

What is the Premier using this bit of discourse to do here? Given the social situation (an interview with the CBC in direct response to a Saskatchewan school division's policy), it appears Wall is trying to contrast his values (and his family's) with those of the Saskatoon Public School Board. Wall's social activity positions himself to the audience in opposition to an unstated group, which can be implicitly inferred by the listener as the School Board. Note the critical phrasing "We ask our kids to get their assignments in on time." Wall establishes his personal values as expressions of a family-centered ethic, leaving the listener to wonder about the ethic of his implied opposition. If Wall asks his children to hand their work in promptly, what does the School Board ask? When Wall says, "We need to be providing an education for young Saskatchewan people," he is tacitly implying that presently the Board's modified policy is not providing a sufficient education for young people by virtue of its policy proposal. This kind of oppositional positioning utilizes an unarguable common sense. Who would argue that students shouldn't hand things in on time? Who would argue against a quality education for Saskatchewan's children? However, Wall's positioning obfuscates that Board's true policy, which is not to encourage tardiness or plagiarism, but rather to deal with it in a separate manner. In short, he is using this discursive opportunity to create public opposition for the proposed assessment changes.

What kind of identity is Wall trying to enact here? By identity, I mean how individuals use Discourse (Gee, 1996) to demonstrate their affiliation with a particular social group, how people demonstrate through talk that they are those "kinds of people." In Wall's case, his appeal to his own family's narrative enacts his identity as a supporter of traditional values. This correlation between what he expects at home and what should be expected at school characterizes him as resonant with a neoconservative discourse. In addition, he contextualizes this identity in relationship to his belief in a correlation between the work of school and the needs of the labour force. This ethic of schools as sites of preparation "for the workforce" aligns Wall with a neoliberal ideology, as an individual who values schools as corresponding to particular market needs.

How is Wall internally connecting things? It is clear through his discourse that he believes that his espoused family values and the ethic of work are connected and related to one another. This fusing is the very definition of conservative modernization. Apple (2000) describes this kind of subtle discursive work:

The free-market ethic has been combined with populist politics. This has meant the blending together of a "rich mix" of themes that have had a long history-nation, family, duty, authority, standards, and traditionalism - with other thematic elements that have also struck a resonant chord during a time of crisis. These latter themes include self-interest, [and] competitive individualism. (p. 22) 
Combining these two elements—-neoliberal and neoconservative-helps discursively construct an identity, and set the group rules for what is perceived of as common sense for the scope of the argument.

This is only one instantiation of this kind of conservative modernization discourse at work in the province; if space permitted, it would be valuable to further explore other examples of this kind of discursive work at large in Saskatchewan; however, my intent in this article is simply to raise broader awareness by focusing on a single incident. The public outrage against the proposed separation of academic evaluation and behaviour is a conditioned response, and stems from a deep distrust of unconventional knowledge and modes of thought that run contrary to the present ethic. In many ways, the fierce backlash from seemingly all sectors to the Saskatoon Public School Board's assessment guidelines demonstrates the pervasiveness of a conservative modernization ideology. Most critiques were couched in the dual language of traditional values — “Saskatoon schools go easy on plagiarism” — and market readiness — “such an approach does not prepare students for the real world" (CBC, September 28, 2010). Much work is yet to be done to both demonstrate the pervasiveness of this type of discourse and provide linkages between its prominence and broader forms of economic reasoning.

\section{Conclusion}

To borrow a question-answer structure from Gee (2005, p. 4), am I accusing various groups of using language for political purposes? If this means that I am saying Premier Wall, the CBC, and the Ministry of Education are creating situated identities with substantial political consequences, then the answer is unequivocally yes. It could not be otherwise, however. The very constitution of language means it is intrinsically bound up with the politics of representation and the hierarchies of identity (Fairclough, 2005; Gee, 1996). There is no neutral way of describing, critiquing, or discussing something that does not call upon the linguistic resources of a language and in turn position the speaker and object of discussion in political ways.

In the case of our example of the Premier's commentary on the assessment controversy, Wall is engaging in a very real social project that both reflects and creates new identities. His text is both illustrative and constitutive of a particular ideology; his text demonstrates an ideology and "does work" in promoting a conservative modernization approach to education, thanks in no small part to his powerful position as head of the Saskatchewan government. This is not to say that he is imposing an ideological vision on the province; his words would not have resonance with the broader populace if this kind of vision of schools were not already present in some segments of the population. This eschews simple cause-and-effect language. Such is the difficulty in describing ideology and in characterizing discourse as an inherently social phenomenon.

My purpose in this article has been to articulate schooling as a form of labour (Apple, 1986; Kincheloe, 1998), both for teachers and students. This means we must think of schools in terms of a political economy, of which grading and mental work are core components. In the confines of a school, grades function as a form of socialization into habits of labour (on time, of your own individual design, etc.) and as a metaphoric wage for the students. When this political economy is transformed, limited, or restricted, it is often the result of the incursion of a particular ideology of the relationship between school and the economy. The question is, then, to articulate what type of ideology is at work. In the case of Saskatchewan, it would appear that an ideology 
of conservative modernization is being deployed to articulate a vision of what kind of curricular reform should be possible for schools.

When the Saskatoon Public School Board sought to modify the political economy of the school as expressed through their assessment guidelines, they soon discovered another ideology at work in the broader populace that had a starkly different ideal for the purpose of assessment. Separating assessment from behaviour was viewed by the public as a diminishment of a tacit sociological process of schooling that had a direct correlation to labour/virtuous habits that various interest groups wished to see inculcated in students. To deploy a more critical language, the shift by the Saskatoon Public School Board represented a diminishment of the overt correspondence between the needs of capital and the day-to-day cultural work of the classroom (Giroux, 1980). By detaching the wage (in the form of grades) from desired behavioural outcomes, schools were not actually encouraging plagiarism or lateness; it is crucial to restate that these behaviours were still to be dealt with through detention, work duties, suspension, or many of the other mechanisms schools have at their disposal. Rather, the Saskatoon Public School Board was constructing a political economy of student work that rewarded achievement in a way contrary to the socialized needs of various interest groups.

Undertheorization of this process would articulate it as bare reproduction (Apple, 1979; Bowles \& Gintis, 1976). However, a more thoughtful approach to the expression of ideology in schooling seeks to understand the integration of various truth claims into the broader populace through mechanisms that are economic, but also cultural, social, and linguistic. Seemingly disparate groups (capital, family values, etc.) are marshalled to present a unique identity of opposition. One is not the master of the others. To borrow language from Althusser (1969), the semiotic work of "family values" retains "relative autonomy" but works in consultation with the articulated needs of capital to form what Apple (2000) calls conservative modernization. Ideology and the process of schooling are always sites of contestation, and the intentions of the government, the media, parents, or teachers are not necessarily what is occurring at the day-today level of actual practice.

I am not arguing there is an ideological univocality at work here, or that the public and governmental quashing of the proposed reform can be narrowed to a single ideological cause. There is undoubtedly a multiplicity of factors and ideologies at work in this instance. This is not to say, however, that there is not a predominant discourse presently operating in Saskatchewan educational circles, and that this discourse does not have the capacity to set the agenda when it comes to the kind of reform currently possible. This is a claim of linguistic re-articulation (Hall, 1978), that language with emotional economy (families, values, accountability, etc.) is appropriated in a cultural field in order to be deployed to service a particular ideology. A vision of schools as sites for the sole expression of conservative modernization values is a severe restriction of the public imagination, and a divorce from the kind of thoughtful, broader, and, yes, radical expressions of what schools might be (Dewey, 1998; Freire, 1970; McLaren, 2000). I do not argue that the Saskatoon Public School Board's proposed reforms were such an expression. Rather, I simply wish to illustrate how the condemnatory response to the reforms demonstrates the predominance of an ideology that has little room for models of education that do not adhere to tacit beliefs about the socialization of students into a particular kind of work that requires particular habits of mind. What are the possibilities for change, for the articulation of a different vision of schools? One small step is to acknowledge and confront this narrowness of thought. Michael Apple (1982) asks, "How do we know what non-reproductive activity is 
occurring if we do not participate in it ourselves?” ( p. 177). Practice does not change unless we acknowledge the ideology implicit in policy decisions, and unless we take seriously the capacity of broader economic and sociological processes to limit the capacity of reform. 


\section{References}

Althusser, L. (1969). Contradiction and overdetermination. In For Marx (pp. 87-128). New York: Random House.

Apple, M.W. (1979). Ideology and curriculum. New York, NY: Routledge \& Kegan Paul.

Apple, M.W. (1980). The other side of the hidden curriculum: Correspondence theories and the labor process. Journal of Education, 162(1), 47-66.

Apple, M.W. (1982). Education and power. Boston \& London: Routledge \& Kegan Paul.

Apple, M.W. (1986). Teachers \& texts: A political economy of class \& gender relations in education. New York \& London: Routledge.

Apple, M.W. (1996). Cultural politics and education. Buckingham, UK: Open University Press.

Apple, M.W. (2000). Official knowledge: Democratic education in a conservative age (2nd ed.). New York, NY: Routledge.

Apple, Michael W. (2006). Educating the "right" way: Markets, standards, God, and inequality (2nd ed.). New York, NY: Routledge.

Bacchi, C.L. (1999). Women, policy and politics: The constructions of policy problems. London: Sage.

Bernier, N.R., \& Williams, J.E. (1973). Beyond beliefs: Ideological foundations of American education. Englewood Cliffs, NJ: Prentice-Hall.

Bourdieu, P., \& Passeron, J.C. (1977). Reproduction: In education, society, and culture. Beverly Hills, CA: Sage.

Bowles, S., \& Gintis, H. (1976). Schooling in capitalist America: Educational reform and the contradictions of economic life. New York, NY: Basic Books.

Cameron, D. (2008). Essential Services Legislation: Will it facilitate or impair industrial relations? Saskatchewan Notes_Canadian Centre for Policy Alternative, 7(1), 1-4.

Campbell, D. (2011). Inside Saskatchewan and the art of the boom. Alberta Oil: The Business of Energy. Retrieved from http://www.albertaoilmagazine.com/2011/04/staying-hot/

CBC News. (2010, September 27). Saskatoon schools go easy on plagiarism. CBC Saskatchewan News. Retrieved from http://www.cbc.ca/canada/saskatchewan/

CBC News. (2010, September 28). Saskatoon's new student evaluations a concern: professor. CBC Saskatchewan News. Retrieved from http://www.cbc.ca/canada/saskatchewan/

CBC News. (2010, September 29). Sask. premier uneasy about student evaluations. CBC Saskatchewan News. Retrieved from http://www.cbc.ca/canada/saskatchewan/

CBC News. (2010, September 30). Plagiarism still gets a zero, board chair says. CBC Saskatchewan News. Retrieved from http://www.cbc.ca/canada/saskatchewan/

CBC News. (2010, October 5). Sask. tells schools not to condone plagiarism. CBC Saskatchewan News. Retrieved from http://www.cbc.ca/canada/saskatchewan/

Coles, S., \& Morrison, R. (2010, September 30). Saskatoon public school board reacts. CBC Saskatchewan News. Retrieved from http://www.cbc.ca/canada/saskatchewan/ 
Dale, R. (1989). The Thatcherite project in education. Critical Social Project, 9(3), 4-19.

Dewey, J. (1998). Experience and education. West Lafayette, Indiana: Kappa Delta Pi.

Epstein, K. (2006, October 16). No Bush Left Behind. Bloomberg Businessweek. Retrieved from http://www.businessweek.com/magazine/content/06_42/b4005059.htm

Erickson, F. (1988). School literacy, reasoning, and civility: An anthropologist's perspective. In E. Kintgen, B. Knoll, \& M. Rose (Eds.), Perspectives on Literacy (pp. 205-226). Carbondale, IL: Southern Illinois University Press.

Fairclough, N. (1989). Language and power. London: Longman.

Fairclough, N. (2005). Critical discourse analysis: The critical study of language. London: Pearson.

Fraser, N. (1991). The uses and abuses of French discourse theories for feminist politics. In P. Wexler (Ed.), Critical theory now (pp. 98-117). London: Falmer Press.

Freire, P. (1970). Pedagogy of the oppressed. New York, NY: Continuum.

Friedman, T. (2005). The world is flat: A brief history of the Twenty-first century. New York: Farrar, Straus and Giroux.

Gee, J.P. (1992). The social mind. New York: Bergin \& Garvey.

Gee, J.P. (1996). Social linguistics and literacies: Ideology in discourses. Bristol, PA: Taylor \& Francis.

Gee, J.P. (2005). An introduction to discourse analysis: Theory and method (2nd ed.). New York, NY: Routledge.

Gee, J.P, Hull, G., \& Lankshear, C. (1996). The new work order: Behind the language of the new capitalism. Sydney and Boulder, CO: Allen and Unwin and Westview Press.

Giroux, H.A. (1980). Beyond the correspondence theory: Notes on the dynamics of educational reproduction and transformation. Curriculum Inquiry, 10(3), 225-247.

Giroux, H.A. (1981). Ideology, culture and the process of schooling. Philadelphia, PA: Temple University Press.

Goddard, R. (2009). Not fit for purpose: The national strategies for literacy considered as an endeavour of government. Power and Education, 1(1), 30-41.

Graff, H. (1987). The legacies of literacy: Continuities and contradictions in Western society and culture. Bloomington, Indiana: Indiana University Press.

Hall, S. (1978). Popular culture, politics, and history. Popular Culture Bulletin, 3. Open University duplicated paper.

Harvey, D. (2005). A brief history of neoliberalism. Oxford, UK: Oxford University Press.

Harvey, D. (2006). Spaces of global capitalism: A theory of uneven geographical development. London: Verso.

Heap, J.L. (1980). What counts as reading: Limit to certainty in assessment. Curriculum Inquiry, 10(3), 265-292. 
Jones, A. (1991). 'At school I've got a chance'-Culture/Privilege: Pacific islands and Pakeha girls at school. Palmerston North: Dunmore Press.

Kincheloe, J.L. (1998). How do we tell the workers?: The socioeconomic foundations of work and vocational education. Boulder, CO: Westview Press.

Lankshear, C., \& Gee, J.P. (1997). Language, literacy and the new work order. In C. Lankshear (Ed.), Changing literacy (pp. 83-102). Buckingham, UK: Open University Press.

Li, H. (2003). The resolution of some paradoxes related to reliability and validity. Journal of Educational and Behavioral Statistics, 28(1), 89-95.

Leo, G. (2010, September 30). Student evaluation in other parts of the province. CBC Saskatchewan News. Audio retrieved from http://www.cbc.ca/canada/saskatchewan/

McLaren, P. (2000). Paulo Freire's pedagogy of possibility. In S. Steiner (Ed.) Freirian pedagogy, praxis, and possibilities: Projects for the new millennium. (pp. 1-22). New York: Falmer.

McMillan, J. (2007). Classroom assessment: Principles and practice for effective instruction. Boston, MA: Allyn and Bacon.

McNeil, L. (1988). Contradictions of control: School structure and school knowledge. New York: Routledge.

Ministry of Advanced Education, Employment, and Labour. (2008). Saskatchewan people continue to benefit from economic boom. Government of Saskatchewan News Release. Regina, SK: Ministry of Advanced Education, Employment, and Labour.

Ministry of Finance (2011). Tax cuts of 2008 more effective than first estimated. Government of Saskatchewan News Release. Regina, SK: Ministry of Finance.

New West Partnership (2010). New West Partnership Trade Agreement. Governments of British Columbia, Alberta, and Saskatchewan Publication. Regina, SK: Executive Council of Intergovernmental Affairs - Trade Policy.

Saskatchewan Ministry of Education (2008). Pre-K-12-Continuous improvement framework: A guide for school division strategic planning-Version III. Retrieved from http://www.education.gov.sk.ca/CIF

Saskatchewan Ministry of Education. (2010a). Communications 10, 20, 30. Retrieved from http://www.education.gov.sk.ca/adx/aspx/adxGetMedia.aspx?DocID=7087

Saskatchewan Ministry of Education. (2010b). English Language Arts 1. Retrieved from http://www.education.gov.sk.ca/adx/aspx/adxGetMedia.aspx?DocID=6821

Saskatchewan Party (2007). Securing the future: New ideas for Saskatchewan. Regina, SK: The Saskatchewan Party.

Street, B. (1995). Social literacies: Critical approaches to literacy in development, ethnography and education. New York: Longman.

The Economist. (2008, June 5). Not Just a breadbasket: Saskatchewan becomes the new Alberta. The Economist. Retrieved from http://www.economist.com/node/11497012

Willis, P. (1977). Learning to labour. Farnborough: Saxon House. 
Yu, C.H. (2005). Test-retest reliability. In K. Kempf-Leonard (Ed.). Encyclopedia of social measurement (Vol. 3, pp. 777-784). San Diego, CA: Academic Press. 